\title{
NGHIÊN CỨU NỒNG Độ NT-pro BNP Ở BÊNNH NHÂN SUY TIM DO TĂNG HUYẾT ÁP
}

\section{TÓM TẮT.}

Mục tiêu nghiên cứu: Xác định sự biến đổi nồng độ NT-pro BNP huyết thanh và mối liên quan giữa nổng độ NT-pro BNP huyết thanh với một số chỉ số lâm sàng, cận lâm sàng ở bệnh nhân suy tim do tăng huyết áp. Đối tượng và phương pháp nghiên cứu: Nghiên cứu mô tả cắt ngang được thực hiện trên 120 bểnh nhân suy tim do tăng huyết áp để khảo sát nồng đổ NT-pro BNP. Kết quả: (1) Giá trị trung bình nồng độ NT-pro BNP huyết thanh của bệnh nhân suy tim do tăng huyết áp ở nhóm giai đoạn A là 2168,92 $\pm 2884,87 \mathrm{pg} / \mathrm{ml}$, giai đoạn B là $2826,2 \pm 1743 \mathrm{pg} / \mathrm{ml}$, giai đoạn C là $11137,83 \pm 8058 \mathrm{pg} / \mathrm{ml}$, giai đoạn $\mathrm{D}$ là $16213,51 \pm 10944,03 \mathrm{pg} / \mathrm{ml}(\mathrm{p}<0,05) ;(2)$ Nồng độ NT-pro BNP huyết thanh có mối tương quan thuận chặt chẽ với các giai đoạn suy tim theo AHA/ACC-2008 $(r=0,63 ; p<0,05) ;(3)$ Có mối tương quan giữa nồng độ NT-pro BNP huyết thanh với phân độ suy tim theo NYHA $(r=0,53 ; p<0,05)$ và (4) Chưa thâyy có sự tương quan giứa nồng độ NT-pro BNP huyết thanh với: chỉ số khối cơ thể, mức lọc cầu thân, hematocit ở bệnh nhân suy tim do tăng huyết áp. Kết luận: Nồng độ NT-pro BNP huyết thanh tăng cao ở bệnh nhân suy tim do tăng huyết áp và nồng độ chất này trong huyết thanh tương quan thuận với giai đoạn suy tim theo AHA/ACC-2008 và mức độ suy tim theo NYHA.

Tư khóa: NT-pro BNP huyết thanh, suy tim, tăng huyết áp

\section{SUMMARY \\ SERUM NT-prO BNP CONCENTRATIONS IN \\ PATIENTS WITH HEART FAILURE DUE TO HYPERTENSION}

Research objectives: To determine the variation in serum NT-pro BNP concentrations and the relationship between serum NT-pro BNP concentrations with some clinical and subclinical indicators in patients with heart failure due to hypertension. Subjects and research methods: Cross-sectional descriptive studies that were performed on 120 patients with heart failure due to hypertension to survey the concentration of serum NTpro BNP. Results: (1) The mean concentration of serum NT-pro BNP of patients with heart failure due to hypertension in the stage A group was $2168,92 \pm$ $2884.87 \mathrm{pg} / \mathrm{ml}$, the stage B group was $2826,2 \pm 1743$ $\mathrm{pg} / \mathrm{ml}$, the stage $C$ group is $11137,83 \pm 8058 \mathrm{pg} / \mathrm{ml}$, the stage $D$ group is $16213,51 \pm 10944,03 \mathrm{pg} / \mathrm{ml}(\mathrm{p}$ $<0,05)$; (2) the concentration of serum NT-pro BNP

${ }^{1}$ Trường Đại hoc Y khoa Vinh

Chịu trách nhiệm chính: Nguyễn Văn Tuấn

Email: tuanminh1975@gmail.com

Ngày nhận bài: 15.6.2021

Ngày phản biên khoa học: 17.8.2021

Ngày duyệt băi: 23.8.2021

\section{Nguyễn Văn Tuấn ${ }^{1}$, Trần Thị Kiều Anh ${ }^{1}$}

has a strong positive correlation with heart failure stages (according to AHA/ACC-2008) ( $r=0.63 ; p$ $<0.05)$; (3) There was a correlation between the concentration of serum NT-pro BNP with NYHA degree of heart failure $(r=0.53 ; p<0.05)$ and (4) There has been no correlation between the concentration of serum NT-pro BNP with: BMI, GFR and Hematocrit. Conclusion: The concentration of serum NT-pro BNP were elevated in patients with heart failure due to hypertension and it positively correlate with the stage of heart failure according to AHA/ACC-2008 and degree of heart failure according to NYHA.

Keywords: serum NT-pro BNP, heart failure, hypertension

\section{I. ĐăT VẤN ĐỀ}

Tăng huyết áp là bệnh lý thường gặp với tỷ lệ mắc bênh cao. Tăng huyết áp là yếu tố nguy cớ độc lập đối với tổn thương tim mạch và là nguyên nhân hàng đâu gây suy tim. Để chẩn đoán suy tim do tăng huyết áp ngoài các biểu hiện lâm sàng và cận lâm sàng như điện tâm đồ, siểu âm tim,... thì hiện nay vai trò của $\mathrm{N}$-terminal pro B-type natriuretic peptide (NT-pro BNP) cũng được nghiên cứu nhiều với vai trò là một dấu ấn trong chẩn đoán và theo dõi tình trạng suy tim của bệnh nhân. NT-pro BNP là một peptid được tiết $70 \%$ từ cơ thất và một lượng nhỏ từ cơ nhĩ. Các nghiên cứu đã cho thấy có sự liên quan giữa áp lực cuối tâm trương thất trái với nồng độ NTpro BNP huyết thanh. Sự phóng thích NT-pro BNP huyết thanh được điều tiết bởi cả áp lực và thể tích thất trái. Tình trạng gia tăng sức căng thành cơ tim là yếu tố kích thích mạnh mẽ sự phóng thích NT-pro BNP[2]. Với mục đích tìm hiểu sự biến đổi nồng độ NT-pro BNP ở bệnh nhân suy tim do tăng huyết áp và sự liên quan của nông độ NT-pro BNP với mức độ suy tim, chúng tôi tiến hành nghiên cứu đề tài này với mục tiêu: Xác định sự biến đổi nồng độ NT-pro BNP huyết thanh và mối liên quan giữa nông độ NT-pro BNP huyêt thanh với một số chi số lâm sàng, cận lâm sàng ở bệnh nhân suy tim do tăng huyết áp.

\section{II. ĐỐI TƯỢNG VÀ PHƯƠNG PHÁP NGHIÊN CỨU}

\section{1. Đối tượng nghiên cứu}

1.1. Tiêu chuẩn lựa chọn. Bệnh nhân được chẩn đoán suy tim do tăng huyết áp theo Tiểu chuẩn chẩn đoán suy tim của Hội Tim mạch Châu Âu 2008 [5].

\subsubsection{Tiêu chuân loại trù}


- Bệnh nhân bị suy tim do THA thứ phát.

- Bệnh nhân bị đái tháo đường.

- Bểnh nhân bị phù toàn do xơ gan, do bệnh thận.

- Bệnh nhân có dấu hiệu suy tim do các nguyên nhân khác ngoài tăng huyết áp.

- Bệnh nhân không đồng ý tham gia nghiên cứu.

\subsection{Phương pháp nghiên cứu}

2.2.1. Địa diểm nghiên cứu: Khoa Tim mạch - Bệnh viện Hữu nghị đa khoa Nghệ An.

2.2.2. Thiêt kế nghiên cứu: Nghiên cứu mô tả cắt ngang.

2.2.3. Cõ mẫu và phương pháp chọn mẫu

- Cõ mẫu: 120 bệnh nhân suy tim do tăng huyết áp khám, điều trị tại khoa Tim mạch, Bệnh viện hữu nghị đa khoa Nghệ An được đưa vào nghiên cứu, trong đó: suy tim giai đoạn A: 30 bệnh nhân; suy tim giai đoạn $B: 30$ bệnh nhân; suy tim giai đoạn $C: 30$ bệnh nhân và suy tim giai đoạn D: 30 bệnh nhân

- Phương pháp chọn mẫu: Chọn mẫu thuân tiện, lựa chọn những bệnh nhân đáp ứng đủ tiều chuẩn nghiên cứu để đưa vào nghiên cứu.

2.2.4. Các tiêu chuẩn và công thức áp dụng trong nghiên cứu

\subsubsection{Tiêu chuẩn chẩn đoán suy tim [5]}

Chẩn đoán suy tim theo tiêu chuẩn của Hội Tim mạch Châu Âu 2008:

- Bệnh nhân có triệu chứng đặc hiệu của suy tim (khó thở khi gắng sức, mệt mỏi, phù,...) và

- Có các dấu hiệu thực thể của suy tim (nhịp nhanh, thở nhanh, có ran ở phổi, tĩnh mạch cổ nổi, phù ngoại biên, gan to,...) và

- Có bằng chứng khách quan của tổn thương cấu trúc, chức năng tim khi nghỉ (tim to, tiếng thứ 3, tiếng thổi tâm thu, bất thường trên siêu âm tim, tăng BNP).

\subsubsection{Phân loai mức đô suy tim theo NYHA}

\begin{tabular}{|c|c|}
\hline Đô & Biểu hiên \\
\hline & Bênh nhân có bênh tim nhưng không có \\
\hline I & $\begin{array}{l}\text { triệu chứng cơ nắng nào, vẫn sinh hoạt và } \\
\text { hoạt động thể lực gần như bình thường. }\end{array}$ \\
\hline II & $\begin{array}{l}\text { Các triệu chứng cơ năng chỉ xuất hiện khi } \\
\text { gắng sức nhiều. Bệnh nhân bị giảm nhẹ các } \\
\text { hoạt động về thể lực. }\end{array}$ \\
\hline III & $\begin{array}{l}\text { Các triệu chứng cơ năng xuất hiện kế cả khi } \\
\text { gắng sức rất ít, làm hạn chế nhiều các hoạt } \\
\text { động thể lực. }\end{array}$ \\
\hline
\end{tabular}

IV Các triệu chứng cơ năng tồn tại một cách thường xuyên, kể cả lúc bệnh nhân nghỉ ngơi.

2.2.4.3. Phân giai đoạn suy tim theo AHA/ACC 2008 [5]

\begin{tabular}{|c|c|}
\hline & Đặc điểm \\
\hline & 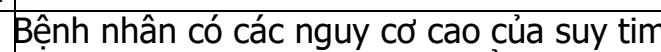 \\
\hline A & $\begin{array}{l}\text { nhưng chưa có } \\
\text { cất }\end{array}$ \\
\hline B & $\begin{array}{l}\text { Bệnh nhân đã có } \\
\text { cấu trúc tim nhưn } \\
\text { biểu hie }\end{array}$ \\
\hline C & $\begin{array}{l}\text { Bệnh nhân đã } \\
\text { hoặc đang có } \\
\text { bệnh gây tó }\end{array}$ \\
\hline & $\begin{array}{r}\text { Bệnh nhân suy } \\
\text { biện ph }\end{array}$ \\
\hline
\end{tabular}

2.2.4.4. Công thức tính chỉ số khối cơ thể (BMI)

$$
\operatorname{BMI}\left(\mathrm{kg} / \mathrm{m}^{2}\right)=\quad \begin{gathered}
\text { Cân nặng }(\mathrm{kg}) \\
--{ }^{2}
\end{gathered}
$$

Nhận định kết quả:

Thẩp cân: $\mathrm{BMI}<18,5$

Bình thường: BMI từ 18,5-22,9

Thừa cân: BMI từ $23-24,9$

Béo phì độ I: BMI từ $25-29,9$

Béo phì độ II: BMI $\geq 30$.

2.2.4.5. Công thức tính mức lọc cầu thận (MLCT). Trong nghiên cứu này chúng tôi ước tính MLCT dựa vào công thức CKD-EPI (Chronic Kidney Disease Epidemiology Collaboration):

$\operatorname{MLCT}\left(\mathrm{ml} / \mathrm{ph} / 1,73 \mathrm{~m}^{2}\right)=141 \times \mathrm{min}(\mathrm{Scr} / \mathrm{k}, 1)^{\mathrm{a}}$ $x \max (\mathrm{Scr} / \mathrm{k}, 1)^{-1,209} \times 0,993^{\text {tuổi }} \times 1,018$ (nếu là nữ) x 1,159 (nếu là người da đen).

Trong đó: Scr: nồng độ creatinin huyết thanh $(\mathrm{mg} / \mathrm{dL}) ; \mathrm{k}:$ nữ $=0,7 ;$ nam $=0,9$

a: nữ $=-0,329 ;$ nam $=-0,411$

min: số nhỏ nhất của $\mathrm{Scr} / \mathrm{k}$ hoặc $=1$

max: số lớn nhất của $\mathrm{Scr} / \mathrm{k}$ hoặc $=1$

Tuổi: tính theo năm

2.2.5. Phương pháp xử lý số liệu: - Số liệu được xử lý bằng phần mềm SPSS 20.0.

- Nồng độ NT-pro BNP được biểu thị bằng Trung bình (TB) \pm độ lệch chuẩn (SD).

- Sử dụng ANOVA test để so sánh trung bình các quan sát và sử dụng test $X 2$ để so sánh sự khác biệt về tỷ lệ phần trăm.

\section{KẾT QUẢ NGHIÊN CỨU}

Bảng 1. Nông độ NT-pro BNP huyêt thanh theo từng giai đoạn suy tim do tăng huyêt áp

\begin{tabular}{|c|c|c|c|c|c|}
\hline \multirow{2}{*}{ Chỉ số } & \multicolumn{4}{|c|}{ Giai đoạn suy tim } & \multirow{2}{*}{$\mathrm{p}$} \\
\cline { 2 - 5 } & $\mathrm{A}(\mathrm{n}=30)$ & $\mathrm{B}(\mathrm{n}=30)$ & $\mathrm{C}(\mathrm{n}=30)$ & $\mathrm{D}(\mathrm{n}=30)$ & \multirow{2}{*}{} \\
\hline NT-pro BNP & $2168,92 \pm$ & $2826,2 \pm$ & $11137,83 \pm$ & $16213,51 \pm$ & $<0,005$ \\
(pg/ml) & 2884,87 & 1743,56 & 8058,43 & 10944,03 & \\
\hline
\end{tabular}




\begin{tabular}{|c|c|c|c|c|c|}
\hline $\mathrm{Ln}$ & $1447,97 \pm 987,76$ & $2807 \pm 2134,02$ & $10422,49 \pm 8081,98$ & $13350 \pm 12139,42$ & $<0,05$ \\
\hline$r$ & \multicolumn{3}{|c|}{$r=0,63$} & $<0,001$ \\
\hline
\end{tabular}

Nhận xét: Nồng độ NT-pro BNP ở nhóm bệnh nhân giai đoạn suy tim nặng hơn cao hơn có ý nghĩa thống kê so với nhóm bênh nhân giai đoạn suy tim nhẹ hơn $(p<0,05)$.

Bảng 2. Giá trị điểm cằt nồng độ NT-pro BNP huyết thanh trong chẩn đoán suy tim theo các giai đoan theo ACC/AHA

\begin{tabular}{|c|c|c|c|c|}
\hline Giai đoạn suy tim & $\begin{array}{c}\text { Điếm cắt giới } \\
\text { hạn (pg/ ml) }\end{array}$ & Độ nhạy & $\begin{array}{c}\text { Độ đặc } \\
\text { hiệu }\end{array}$ & $\begin{array}{c}\text { Diện tích dưới } \\
\text { đường cong ROC }\end{array}$ \\
\hline A & $\leq 2489$ & $75,00 \%$ & $82,26 \%$ & 0,849 \\
\hline B & $\leq 3759$ & $73,68 \%$ & $63,38 \%$ & 0,675 \\
\hline C & $>5265$ & $77,78 \%$ & $70,83 \%$ & 0,708 \\
\hline$D$ & $>5799$ & $84,00 \%$ & $75,38 \%$ & 0,852 \\
\hline
\end{tabular}

Nhận xét: Nồng độ NT-pro BNP của các giai đoạn A, B, C và D lần lượt có điếm cắt là 2489 $\mathrm{pg} / \mathrm{ml}, 3759 \mathrm{pg} / \mathrm{ml}, 5265 \mathrm{pg} / \mathrm{ml}$ và $5799 \mathrm{pg} / \mathrm{ml}$.

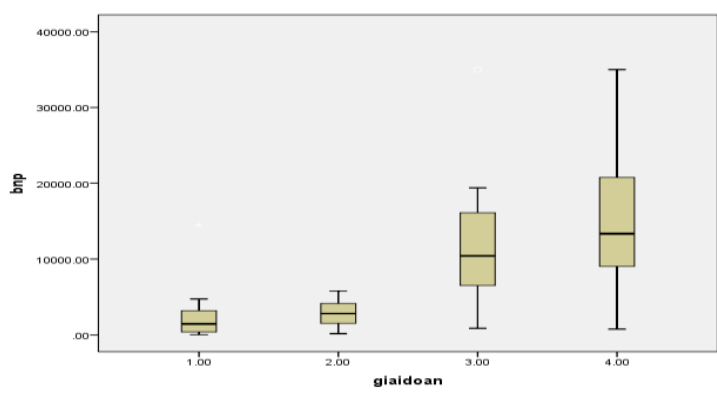

Biểu đồ 1. Môí tương quan giữa NT-pro BNP với các giai đoạn trong quá trinh tiến triên cúa suy tim theo ACC/AHA

Nhân xét: Hệ số tương quan $\mathrm{r}=0,63 ; \mathrm{p}<$ 0,005. Có mối tương quan thuận giữa nồng độ NT-pro BNP huyết thanh với các giai đoạn $A, B, C, D$ trong quá trình tiến triển của suy tim do tăng huyết áp.
Bảng 3. Môi liên giữa NT-pro BNP với phân độ suy tim theo NYHA

\begin{tabular}{|c|c|c|}
\hline \multirow{2}{*}{$\begin{array}{c}\text { Phân độ } \\
\text { suy tim } \\
\text { theo NYHA }\end{array}$} & \multicolumn{2}{|c|}{$\begin{array}{c}\text { Nồng độ NT-pro BNP } \\
\text { (pg/ml) }\end{array}$} \\
\cline { 2 - 3 } & $\mathbf{X} \pm$ SD & Ln X I SD \\
\hline \multirow{2}{*}{ NYHA I } & $3412,00 \pm$ & $987,76 \pm$ \\
& 5329,00 & 1447,97 \\
\hline \multirow{2}{*}{ NYHA II } & $6894,74 \pm$ & $2134,02 \pm$ \\
& 10465,02 & 2807,00 \\
\hline \multirow{2}{*}{ NYHA III } & $8189,63 \pm$ & $8081,89 \pm$ \\
& 8089,12 & 10422,49 \\
\hline \multirow{2}{*}{ NYHA IV } & $12648,85 \pm$ & $12139,42 \pm$ \\
& 10318.21 & 13350,00 \\
\hline P & \multicolumn{3}{|c|}{$<0,05$} \\
\hline
\end{tabular}

Nhân xét: Có mối liên quan giữa mức độ năng của suy tim theo phân độ NYHA với nồng độ NT-pro BNP huyết thanh ở bệnh nhân suy tim do tăng huyết áp $(p<0,05)$.

Bảng 4. Mối liên quan giữa nồng độ NT-pro BNP huyêt thanh với một số yếu tố lâm sàng, cận lâm sàng ở từng giai đoạn $A, B, C$ và $D$

\begin{tabular}{|c|c|c|c|c|c|c|c|c|}
\hline \multirow{3}{*}{ Chỉ số } & \multicolumn{8}{|c|}{ Giai đoan suy tim } \\
\hline & \multicolumn{2}{|c|}{$\mathbf{A}$} & \multicolumn{2}{|c|}{ B } & \multicolumn{2}{|c|}{ C } & \multicolumn{2}{|c|}{ D } \\
\hline & $\mathbf{r}$ & $\mathbf{p}$ & $\mathbf{r}$ & $\mathbf{p}$ & $\mathbf{r}$ & $\mathbf{p}$ & $\mathbf{r}$ & $\mathbf{p}$ \\
\hline Tuối & 0,33 & 0,01 & 0,30 & 0,90 & 0,01 & 0,20 & 0,17 & 0,098 \\
\hline Giới & 0,30 & 0,01 & 0,10 & 0,013 & 0,28 & 0,013 & 0,2 & 0,003 \\
\hline BMI $\left(\mathrm{kg} / \mathrm{m}^{2}\right)$ & $-0,02$ & 0,18 & 0,15 & 0,006 & 0,26 & 0,48 & 0,23 & 0,78 \\
\hline $\begin{array}{c}\text { MLCT } \\
\left(\mathrm{ml} / \mathrm{ph} / 1,73 \mathrm{~m}^{2} \mathrm{da}\right)\end{array}$ & $-0,14$ & 0,20 & 0,37 & 0,043 & 0,08 & 0,48 & 0,06 & 0,89 \\
\hline Hematocrit $(I / I)$ & $-0,09$ & 0,46 & 0,14 & 0,012 & 0,03 & 0,63 & 0,15 & 0,0001 \\
\hline
\end{tabular}

Nhận xét: Chưa thấy có mối tương quan giữa nồng độ NT-pro BNP huyết thanh với chỉ số BMI, MLCT và Hematocrit ở từng giai đoạn suy tim.

Bảng 5. Liên quan giữa nồng độ NT-pro BNP huyêt thanh với các giai đoạn $A, B, C, D$ theo phân nhóm: mú́c lọc cầu thận, Hematocrit

\begin{tabular}{|c|c|c|c|c|}
\hline \multirow{2}{*}{$\begin{array}{c}\text { Hệ số tương } \\
\text { quan }\end{array}$} & \multicolumn{2}{|c|}{ Phân nhóm MLCT (m//ph/1,73m $\mathbf{2}$ da) } & \multicolumn{2}{c|}{ Phân nhóm Hematocrit (I/I) } \\
\cline { 2 - 5 } & $30-59,9$ & $>60$ & $30-39 \%$ & $>40 \%$ \\
\hline $\mathrm{r}$ & 0,54 & 0,63 & 0,71 & 0,68 \\
\hline $\mathrm{p}$ & $<0,005$ & $<0,01$ & $<0,05$ & $<0,005$ \\
\hline
\end{tabular}

Nhận xét: Có mối tương quan giữa nồng độ NT-pro BNP huyết thanh với các giai đoạn suy tim $A$, $B, C$ và $D$ theo từng phân nhóm mức lọc cầu thận và Hematocrit $(p<0,01)$. 


\section{BÀN LUẬN}

Nồng độ NT-pro BNP huyết thanh trung bình ở nhóm bệnh nhân nguy cơ suy tim chưa có tổn thương thực thể tại tim giai đoạn A là 2168,92 \pm $2884,87 \mathrm{pg} / \mathrm{ml}$. Kểt quả này cao hơn nghiên cứu của $A M$ Abudulle và cộng sự [3] với 128 bệnh nhân. Chỉ hơi khác Bayés $A$ và cộng sự [4] nghiên cứu trên 27 bệnh nhân đái tháo đường type 2 chưa biến chứng mạch máu lớn và nhỏ có giá trị nồng độ NT-pro BNP huyết thanh trung bình là $46 \pm 37 \mathrm{pg} / \mathrm{ml}$. Sở dĩ nồng độ NT-pro BNP huyết thanh trong nghiên cứu của chúng tôi cao hơn so với các nghiên cứu khác liên quan đến các yếu tố tuổi, giới và bệnh kèm theo.

Nồng độ NT-pro BNP huyết thanh trung bình của nhóm bệnh nhân suy tim giai đoạn $C$ trong nghiên cứu này là $11137,83 \pm 8058,43 \mathrm{pg} / \mathrm{ml}$. Nghiên cứu này cho thây khi bệnh nhân có triẹu chứng của suy tim thì nồng độ NT-pro BNP huyết thanh tăng rất cao so với nhóm $A, B$. Trong nghiên cứu của chúng tôi nồng độ NT-pro BNP huyết thanh trung bình của nhóm bệnh nhân suy tim giai đoạn $D$ là $16213,51 \pm 10944,03$ pg/ml, sự khác biêtt có ý nghĩa thống kê với $p<0,05$. Kểt quả chúng tôi cao hơn các nghiên cứu khác rất nhiều như của Zaphiriou $A$ và cộng sự [8] là $1537 \mathrm{pg} / \mathrm{ml}$, của Vũ Hoàng Vũ [1] là $2677 \pm$ $957 \mathrm{pg} / \mathrm{ml}$ cao hơn Valle $\mathrm{R}$ với 101 bệnh nhân, giá trị trung bình là $2806 \mathrm{pg} / \mathrm{ml}$. Nhìn chung việc so sánh giữa các nghiên cứu khó khăn vì chọn đối tượng nghiên cứu khác nhau.

Nghiên cứu chúng tôi nhận thấy có sự tương quan giữa NT-pro BNP huyết thanh với các giai đoạn $A, B, C$ và $D$ trong quá trình tiến triển của suy tim theo $A C C / A H A$ với hệ số tương quan $r=$ 0,$63 ; p<0,005$. Có mối tương quan giữa NTpro BNP huyết thanh với các giai đoạn trong quá trình tiến triển của suy tim có ý nghĩa thống kê với $\mathrm{p}<0,005, r=0,63$ chứng tỏ mối tương quan thuận rất chặt, nồng độ NT-pro BNP huyết thanh tăng theo sự tiến triển của bệnh, từ giai đoạn nguy cơ suy tim chưa tổn thương cấu trúc và tăng cao nhất ở nhóm suy tim giai đoạn cuối.

NT-pro BNP huyết thanh tăng theo quá trình tiến triển của suy tim từ giai đoạn $A$ đến giai đoạn $B$, tăng mạnh mẽ nhất là giai đoạn $D$. Suy tim càng nặng thì nồng độ NT-pro BNP huyết thanh càng cao.

Qua nghiên cứu thây rõ có mối tương quan giữa nồng độ NT-pro BNP huyết thanh và phân độ suy tim theo NYHA với $r=0,53 ; p<0,05$. Nghĩa là triệu chứng suy tim càng nặng thì nồng độ NT-pro BNP càng cao.

Phép so sánh nồng độ NT-pro BNP huyết thanh trung bình cho thấy nồng độ NT-pro BNP huyết thanh ở phân nhóm NYHA II lớn hơn NYHA I có ý nghĩa thống kê $p<0,05$. NYHA III lớn hơn NYHA I có ý nghĩa thống kê. Kết quả này tương tự như các nghiên cứu khác: Vũ hoàng Vũ và Januzzi JL, Cao Huy Thông. Kết quả này cũng khác so với một sô công trình nghiên cứu khác do đôi khi khó phân biệt một các rõ ràng bệnh nhân ở NYHA I, NYHAII... phụ thuộc vào nhiều yếu tố như: cảm giác chủ quan của người bệnh, lời khai khi nhập viên.

Theo Clerio và Raymod nồng độ NT-pro BNP huyết thanh tăng ở nữ nhiều hơn nam. Nghiên cứu của Nielsen OW và cộng sự [6] thực hiện trên 2224 bệnh nhân cung nhận thấy nồng độ NT-pro BNP huyết thanh tăng ở nữ nhiều hơn nam. Trong nghiên cứu của chúng tôi, ở nhóm bệnh nhân nguy cơ suy tim chưa tổn thương thực thể tim có hệ số tương quan giữa NT-pro BNP huyết thanh với $r=0,3 ; p=0,01$ đây là tương quan thuận yếu. Nhóm bệnh nhân suy tim giai đoạn C, D không có sự tương quan NT-pro BNP huyết thanh giữa nam và nữ.

Trong nghiên cứu của chúng tôi, chỉ có nhóm A có sự tương quan nhe NT-pro BNP huyết thanh với tuổi với hệ số tương quan $r=0,33 ; p=0,01$. Đây là mối tương quan thuận yếu. Bệnh nhân trong cùng giai đoạn $B, C, D$ không có sự tương quan NT-pro BNP huyết thanh với tuổi. Kết quả này tương tự Hogenhusia J thực hiện 311 bệnh nhân suy tim có phân suất tống máu giảm cho thấy tuổi là yếu tố ảnh hưởng đến nồng độ NTpro BNP huyết thanh. Nghiên cứu của Vũ hoàng Vũ cho thây có sự tương quan giữa nồng độ NTpro BNP huyết thanh và tuổi trong nhóm bênh nhân suy tim với hệ số tương quan $r=0,193$; $p$ $=0,019[1]$.

Trong nghiên cứu này giữa các nhóm không có sự tương quan giữa nồng độ NT-pro BNP huyết thanh và chỉ số khối cơ thể. Theo nghiên cứu của Krauser DG cho thấy nồng độ NT-pro BNP huyết thanh thấp có ý nghĩa ở người quá cân và béo phì. Nghiên cứu của chúng tôi không phản ánh rõ điều này.

Nghiên cứu của chúng tôi không nhận thấy sự tương quan giữa nồng NT-pro BNP huyết thanh với MLCT ở cả bốn nhóm giai đoạn suy tim, bằng phương pháp hồi quy tuyến tính cho biết hệ số tương quan lần lượt là $r=-0,14$; 0,$37 ; 0,08 ; 0,06$. Bằng phép so sánh trung bình cho thấy không có sự khác biệt nồng độ NT-pro BNP huyết thanh giữa các phân nhóm MLCT. Kết quả này tương tự của Vũ hoàng Vũ và Januzzi JL. Trong nghiên cứu của Januzzi JL và cộng sự 
trên 599 bệnh nhân cho thây phân nhóm creatinin máu không ảnh hưởng đến độ chính xác của nồng độ NT-pro BNP huyết thanh trong chẩn đoán suy tim [7].

\section{KẾT LUẬN}

Giá trị trung bình nồng độ NT-pro BNP huyết thanh của bệnh nhân suy tim do tăng huyết áp ở nhóm giai đoạn A là 2168,92 $\pm 2884,87 \mathrm{pg} / \mathrm{ml}$, giai đoạn $B$ là $2826,20 \pm 1743,56 \mathrm{pg} / \mathrm{ml}$, giai đoạn C là 11137,83 $\pm 8058,43 \mathrm{pg} / \mathrm{ml}$ và giai đoạn D là $16213,51 \pm 10944,03 \mathrm{pg} / \mathrm{ml}(\mathrm{p}<0,05)$.

Nồng độ NT-pro BNP huyết thanh có mối tương quan thuận chặt chẽ với các giai đoạn của suy tim theo AHA/ACC-2008 $(r=0,63 ; p<0,05)$ và với phân độ suy tim theo NYHA $(r=0,53 ; p<0,05)$.

\section{TÀl LIÊU THAM KHẢO}

1. Vũ Hoàng Vũ (2008), "Giá trị của NT-pro BNP trong chẩn đoán suy tim", Đại học Y Dược Thành phố Hồ Chí Minh.

2. Austin W., Bhala V. (2015), "Correlation and prognostic utility of BNP and its amino-terminal fragment in patients with chronic kidney disease", American J Clin Pathol. 126: p. 506-512.
3. Abdulle, A.M., et al. (2007), "Plasma N terminal pro-brain natriuretic peptide levels and its determinants in a multi-ethnic population", J Hum Hypertens. 21: p. 647-653.

4. Bayés, A., G.M. Santaló, B.E. Zapico (2004), "Nterminal probrain natriuretic peptide in the emergency diagnosis and in-hospital monitoring of patients with dysapnea and ventricualar dysfuntion", European Journal of Heart Failure, p. 301-308.

5. Dickstein, K., A. Cohen-Solal, G. Filippatos (2008), "ESC guidelines for the diagnosis and treatment of acute and chronic heart failure 2008", Eur J Heart Fail. 10: p. 933-989.

6. Nielsen, O.W., et al. (2003), "Retrospective analysis of the cost-effectiveness of using plasma brain natriuretic peptide in screening for left ventricular systolic dysfunction in the general population", J Am Coll Cardiol. 41: p. 113-120.

7. Januzzi, J.L., et al. (2015), "The N-terminal NTpro BNP investigation of dyspnea in the emergency department (PRIDE) study", Am J Cardiol. 95: p. 948-954.

8. Zaphiriou A, R.S., Murray-Thomas T, Mendez G, (2005), "The diagnostic accuracy of plasma BNP and NTproBNP in patients referred from primary care with suspected heart failure: results of the UK natriuretic peptide study", Eur J Heart Fail. 7: p. 537-541.

\title{
MộT SỐ ĐẶC ĐIỂM HÌNH THÁI KHỚP CẮN HỞ NGƯờI VIỆT NAM TRÊN PHIM SỌ NGHIÊNG TELE TỪ XA (CEPHALOMETRICS)
}

\author{
Đỗ Thị Bình ${ }^{1}$, Nguyễn Thị Bích Ngọc ${ }^{1}$, Nguyễn Thanh Huyền ${ }^{2}$
}

\section{TÓM TẮT}

Khớp cắn hở phía trước là tình trang sai khớp cắn ảnh hưởng nhiều đến hoạt động chức năng và thẩm mỹ. Đồng thời, sự ổn định sau điều trị của loại sai khớp cắn này luôn là thách thức cho bác sĩ chỉnh nha. Nghiên cứu nhằm mục đích mô tả một số đăc điểm hình thái 36 bệnh nhẩn người Việt Nam, độ tuổi từ 1018 tuổi, có khớp cắn hở phía trước trền phim so nghiêng tele từ xa Cephalometric đến khám tại Bệnh viện Răng Hàm Mặt Trung Ương và Viện Đào tạo Rẳng Hàm Mặt. Kết quả nghiên cứu cho thấy khớp cẳn hở là loại hình sai khớp cắn ít gặp, xuất hiện nhiều ở nữ hởn, tuy nhiên không có sự khác biệt có ý nghĩa thống kê giữa hai giới. Phần lớn cắn hở ở mức độ trung bình $(-1,39 \pm 0,499 \mathrm{~mm})$. Chiếm tỉ lệ nhiều nhất là sai khớp cắn hạng III xương $(n=15 ; 41,7 \%)$, Chiều cao tâng mặt dưới (LAFH) trung bình là $63,41 \pm 6,185 \mathrm{~mm}$ (nữ) và $68,29 \pm 5,341 \mathrm{~mm}$ (nam). Tỉ lệ chiều cao tầng mặt sau/chiêuu cao tâng mặt trước (PFH/AFH) $=0,651 \pm$

${ }^{1}$ Trường Đại học Y Hà Nội

2Bệnh viện Răng Hàm Mặt Trung Ương

Chịu trách nhiệm chính: Đỗ Thị Bình

Email: drbee712@gmail.com

Ngày nhận bài: 22.6.2021

Ngày phản biên khoa học: 18.8 .2021

Ngày duyệt bài: 25.8.2021
0,057 . Chỉ số cắn sâu (ODI) là $61,25 \pm 9,241$, chỉ số loạn sản trước sau (APDI) là 86,97 11,597 , chỉ số kết hợp (CF) là $148,22 \pm 8,642$. Chiêu cao răng hàm lớn thứ nhất hàm trên và hàm dưới lần lượt so với mặt phẳng khẩu cái và mặt phẳng hàm dưới là $\mathrm{d}(\mathrm{U} 6, \mathrm{PP})$

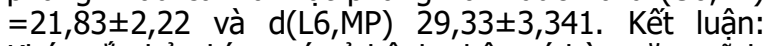
Khớp cắn hở phía trước ở bệnh nhân có hàm răng vĩnh viễn (10-18 tuổi) xuất hiện nhiều ở đối tượng khớp cắn hạng III xương và chiếm phân lớn cắn hở ở mức độ cắn hở mức độ trung bình. Đối tượng này có đặc điểm tăng chiều cao tâng mặt dưới và có kiểu mặt phân ly.

Tư khóa: khớp cắn hở phía trước, cephalometric, người Việt Nam

\section{SUMMARY}

\section{CEPHALOMETRIC CHARACTERISTIC OF} ANTERIOR OPEN BITE IN VIETNAMESE PEOPLE

Anterior open bite (AOB) is a malocclusion that greatly affects function and aesthetics. Besides, longterm stability of $\mathrm{AOB}$ malocclusion is considered challenge for orthodontists. This study aims to describe some morphological characteristics of 36 Vietnamese subjects with anterior open bite between the ages of 10 and 18 years old who had presented the Hanoi Central Odonto-Stomatology Hospital and School of Odonto - Stomatology, Hanoi Medical University. The results of research showed that 